\title{
Accounting For Stock Based Employee Compensation: A Continuing Controversy
}

William Wrege (E-mail: wwrege@bsu.edu), Ball State University Mark Myring (E-mail: mmyring@bsu.edu), Ball State University

Joe Schroeder (E-mail: Joe.Schroeder@ey.com), Ernst and Young

\begin{abstract}
Stock options represent an increasingly significant component of executive compensation. Theoretically, the inclusion of stock options in executive compensation contracts motivates managers to take actions that increase the market value of the firm's stock. Accounting standards regulating the treatment of stock options continue to be controversial. The focus of this paper is to examine the accounting treatment of stock options. We begin by outlining the controversial history of accounting for stock options. Next, we examine the alternative accounting treatments for stock option. Finally, we critique the proposed changes to the methods of accounting for stock options.
\end{abstract}

\section{INTRODUCTION}

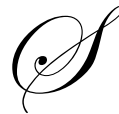

tock options represent an increasingly significant component of executive compensation. Recent surveys show that CEOs receive between 60 and 80 percent of their total compensation from stock options (Business Week 2000, Henry et al. 2002,). Theoretically, the inclusion of stock options in executive compensation contracts motivates managers to take actions that increase the market value of the firm's stock. Specifically, stock options tie compensation to stock price; when executives engage in actions which increase stock price, their compensation increases. Thus, stock options help to align the goals of management with the goals of the firm's stockholders.

Accounting standards regulating the treatment of stock options continue to be controversial. ${ }^{1}$ Prior to 1995 , accounting for stock options was governed by APB Opinion No. 25, Accounting for Stock Issued to Employees (APB 25). Under APB 25, compensation expense from stock options occurred only when options had intrinsic value: that is when the market price at the measurement date, usually the date of grant, exceeded the exercise price of the options. In October 1995, the Financial Accounting Standards Board (FASB) issued Statement of Financial Accounting Standards No. 123, Accounting for Stock Based Compensation (SFAS 123). The standard required the disclosure of the fair market value of stock options granted in executive compensation packages. With the devastating impact of recent accounting scandals, the original debates have been even more vigorously rekindled. The FASB has recently issued an exposure draft which will potentially require expense treatment for stock options.

The focus of this paper is to examine the accounting treatment of stock options. We begin by outlining the controversial history of accounting for stock options. Next, we examine the alternative financial reporting treatments for stock options under U.S. accounting standards. Finally, we will identify advantages and disadvantages of the Exposure Draft treatment of stock options.

\footnotetext{
${ }^{1}$ Street, Fordham and Waylan (1997) document the controversy surrounding stock options through an analysis of newspaper and business magazine articles between 1975-1993.
} 


\section{A BRIEF HISTORY OF STOCK OPTIONS}

The use of stock options was necessitated by separation of company ownership and management, which became common as companies grew large during the industrial revolution. By the 1920s, many formerly family-run enterprises were being run by professional managers. After the Great Depression, many people were left analyzing what had gone wrong with capitalism. Adolf Berle and Gardiner Means, loyal New Dealers, "argued that the rise of professional managers had given business executives de facto power to appropriate shareholder assets...[but] the way to save capitalism... was not to bar managers from pursuing their own interests but to regulate their doing so" (Shapiro 2002, p. 2).

This became the basis of what is now referred to as the agency problem. The agency problem: how to get a manager (agent) to act in the best interest of shareholder-owners (principal) when the agent has both more information and different interests than the principal. The use of compensatory stock options provide a potential solution to this problem. A stock option gives managers the right to purchase common stock at a specific price over an extended period of time. Most people believe that if the company succeeds, the market price of the stock will increase. Therefore, the company's success is directly related to the manager's compensation. This helps motivate managers to take actions that maximize firm value and thus their compensation.

Recognition of the ability of stock options to mitigate the agency problem has increased their popularity. Stock options began to appear modestly in the 1950s, but their popularity began to grow quickly in the 1970s. By $1980,30 \%$ of top managers were receiving stock options, and by 1994, 70\% were. By 2000 top managers were receiving stock options, often amounting to $\$ 30$ to $\$ 55$ million a year. The appropriate method of accounting for stock options has grown in importance as the use of stock options as a component of executive compensation has increased.

\section{ACCOUNTING FOR STOCK OPTIONS}

The prevalent theory is that stock options represent an operating cost to the company, a form of compensation. Therefore, to be consistent with the conceptual framework of the FASB, the cost of this type of compensation should be reflected in the income statement and matched against the benefits over the employee service period.

In 1972, the Accounting Principles Board (APB) Opinion No. 25, Accounting for Stock Issued to Employees, defined a way to account for stock options. Under APB 25, compensation expense related to stock options was recognized only when such plans had intrinsic value (i.e., if the market price was higher than the exercise price). Since the exercise price was typically fixed at the market price on the grant date, compensation expense was seldom recognized under option plans.

Because of perceived shortcomings of APB 25, the FASB added a project to its agenda to reexamine stock option accounting in 1984. Between 1985 and 1988, the FASB conducted research on various aspects of stock based compensation plans. Tentative conclusions, reported in the FASB's Weekly Action Alert, implied that the FASB would require companies to expense the fair value of stock options. Expensing of stock options was criticized by many companies, especially high technology companies in Silicon Valley, who argued that they would have to eliminate stock options if expensing was required by FASB. During Board deliberations from 1985 to 1988, more than 200 letters were received that commented on, and usually objected to, the tentative conclusions reported in the Action Alert (SFAS 123, par. 368).

Later, in June 1992, the Wall Street Journal (WSJ) reported that the FASB had begun a project to examine accounting for stock options (Carlson 1992). Accounting for stock based compensation was addressed at nineteen public board meetings and at two public task force meetings in 1992 and 1993. Again, the tentative conclusion from these meetings to expense stock options was reported in the Action Alert. During this time period, the FASB received more than 450 comment letters, most of which objected to the tentative conclusion (SFAS 123, par. 374). On June 30, 1993, the FASB issued an Exposure Draft on accounting for stock options that required firms to expense the fair value of the options. On May 3, 1994, the U.S. Senate debated a private sector external financial reporting accounting 
standard for the first time in history. After debating, they passed a non-binding resolution, 88 to 9 , expressing opposition to the FASB's proposal (Rubinstein 1995). In total, the FASB received 1,786 comment letters, including 1,000 form letters, most of which objected to the Exposure Draft (SFAS 123, par. 376).

Opponents argued that adoption of the Exposure Draft as the final standard would cause the elimination of stock options from compensation packages. Their main concern was that companies' earnings per share (EPS) would be significantly reduced by recognizing the extra expense, thus hurting their stock prices. This new method would specifically hurt the financial results of start-up technology companies, which used stock option compensation as a way to lure talented executives to run their companies. In fact, recent findings show that the net income of Standard \& Poor's 500 companies would decline $9 \%$ for the year 2000 if an expense were recorded for the fair value of stock options granted (Gleckman 2002).

Under intense criticism from many parties, including Congress and the SEC, and apprehensive about the federal government assuming control of accounting standard setting, the FASB changed the proposed standard. SFAS 123 gives firms the option of expensing the fair value of options in the income statement or applying APB 25 with fair value information disclosed in the footnotes. While the FASB prefers that firms actually expense the fair value of options, this methodology is rarely used because of the significant effect of this expense on net income. Thus, in practice, most firms continue to apply APB 25. Option price is typically set equal to or greater than the market price at the grant date, allowing firms to avoid reporting any income statement expense for options. Pro forma income and earnings per share reflecting the fair market value of stock options as an expense are disclosed in the footnotes of the financial statements.

The controversy surrounding the accounting treatment of stock options has recently received renewed interest in the news media. Enron, among many other companies, was able to boost its income by not expensing stock options granted to employees. Former CEO Kenneth Lay received \$123.4 million from exercising his options in 2000 (Barlas 2002). Many argue that the inappropriate application of accounting standards by Enron was a result of upper management's desire to increase share prices through misstatement of financial information. Occurrences of financial statement fraud have been found to damage the perceived usefulness of disclosures (Nagy 2001).

In response to the renewed media interest, Congress, government officials and business leaders have taken an active interest in the accounting treatment of stock options. Some companies have taken a tougher stance on stock options accounting since the recent accounting scandals have occurred in an attempt to increase investor confidence in their stock. Coca-Cola was one of the first companies to change its accounting method, in July of 2002, from the intrinsic value method to the fair value method and began to recognize stock option expense.

Recently, on March 12, 2003, the FASB announced in a news release the addition of a project that will seek improved financial accounting disclosures of stock-based compensation. This new project will also discuss whether to require companies to expense stock options as opposed to continuing to offer the two different methods allowed in SFAS 123. The project will look into finding better ways to measure stock options expense and the need for one method of accounting for stock options for purposes of consistent financial data (FASB 2003).

On March 21, 2004 the FASB released a new Exposure Draft on stock options entitled "Share-Based Payment - an amendment of FASB Statements No. 123 and 95." This Exposure Draft requires expense treatment for compensatory stock options. As has been the case in the past, this proposed standard has been the subject of intense debate. During the comment period, the FASB received 6,534 letters on the proposed standard, mostly opposing expense treatment for stock options. In the next section of the paper, we provide a detailed outline of the standard.

\section{THE EXPOSURE DRAFT ON STOCK OPTIONS}

In this section of the paper, we examine the recently issued FASB exposure draft concerning the accounting for share-based payments. In particular, liabilities and equity obligations incurred as a result of issuing equity 
instruments with forward looking consequences as compensation to employees for services rendered is the focus of this manuscript (FASB 2004, par. 5). ${ }^{2}$

The primary provision of the Exposure Draft requires that "Public entities should measure the cost of employee services received in exchange for awards of equity instruments based on the fair value of the instruments at the grant date" (FASB 2004, par. 6). In addition, some awards may be classified as liabilities, while most are classified as equity. "This statement requires that the cost resulting from all share-based payment transactions be recognized in the financial statements." (FASB 2004, Appendix A, par. 1) This, of course assumes that such transactions are costs, and a primary question is, which stakeholders suffer these costs? Statement of Financial Accounting Concepts No. 1, Objectives of Financial Reporting by Business Enterprises (CONS \#1), specifies investors and creditors as the primary beneficiaries of external financial reporting.

In some cases, equity instruments granted become liabilities as required under SFAS \#150. When an employee could terminate service and retain the fair value of the instrument that is mandatorially redeemable by the entity, a liability for the instrument fair value is recorded. It is remeasured at the end of each period until it is settled.

On the stock option grant date, the option is assigned a fair value based on the market value of a similar option if one is available. Otherwise, a calculation using an option-pricing model, which takes into account various factors $^{3}$, should be used. The exposure draft encourages, but does not propose to require, use of the so called lattice model, or secondarily the Black-Scholes-Merton formula. The measurement process establishes the fair value of the equity instruments granted to employees. Compensation expense in the amount of the fair value is recognized in the income statement as employees render services.

To show a simple example, assume Bauer Company begins business by issuing 100,000 shares of $\$ 1$ par value stock for $\$ 100,000$. Immediately, the board of directors grants 100,000 options to the company officers who are employees. The exercise price for the shares is $\$ 1$ per share; they vest ratably over the next five years, and are excisable for 10 years from the grant date. The option value is determined to be $\$ .50$ per share. ${ }^{4}$ Each year, the company generates $\$ 25,000$ in sales, and the only expense is $\$ 10,000$ compensation associated with the vesting options $(100,000 \times \$ .50=\$ 50,000 \times 1 / 5=\$ 10,000)$. Each year, the options are exercised on the last day of the year. The income statements for the 5 years and the balance sheet for the fifth year are shown in Exhibit 1 .

\footnotetext{
${ }^{2}$ Other issues addressed in the exposure draft, such as small business issues, cash flow reporting, graded vesting, modifications of awards, replacement awards, etc. are beyond the scope of this paper.

${ }^{3}$ The valuation model should take into account, at a minimum: a. the exercise price of the option, b. the expected term of the option, taking into account both the contractual term of the option and the effects of employees' expected exercise and post-vesting employment terminations behavior, $c$. the current price of the underlying share, $d$. the expected volatility of the price of the underlying share, e. the expected dividends on the underlying share, $f$. the risk-free interest rate for he expected term of the option.

${ }^{4}$ The value of the options is proportional to the example found in paragraphs 60 and 61 of the exposure draft.
} 


\section{EXHIBIT 1: Granted Options Are Exercised}

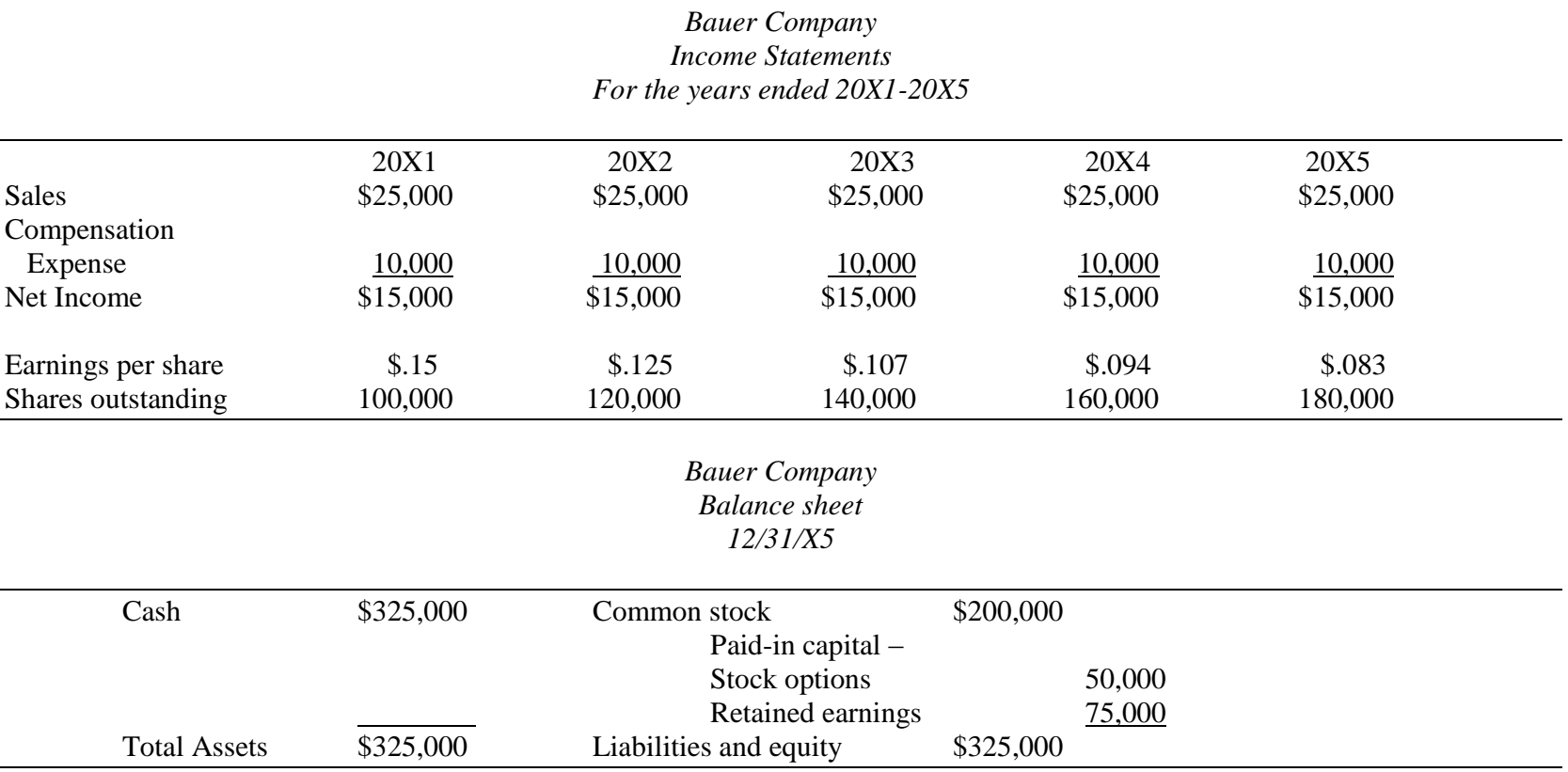

Over the five years the book value of the company rose from $\$ 1.00$ per share to $\$ 1.63$ per share. The net income for the five year period, however, totaled only $\$ .48$. The net income including the charge for employee stock options granted does not appear to reflect economic reality.

If the market price of the stock remained below the exercise price, and the options were never exercised, then the results are as shown in Exhibit 2.

EXHIBIT 2: Granted Options Are Not Exercised

\begin{tabular}{|c|c|c|c|c|c|}
\hline & & $\begin{array}{r}B \\
\text { In } \\
\text { For the } y\end{array}$ & $\begin{array}{l}\text { many } \\
\text { ments } \\
20 X 1-20\end{array}$ & & \\
\hline & $20 \times 1$ & $20 \times 2$ & $20 \times 3$ & $20 \times 4$ & $20 \times 5$ \\
\hline Sales & $\$ 25,000$ & $\$ 25,000$ & $\$ 25,000$ & $\$ 25,000$ & $\$ 25,000$ \\
\hline Compensation & & & & & \\
\hline Expense & $\underline{10,000}$ & $\underline{10,000}$ & $\underline{10,000}$ & $\underline{10,000}$ & $\underline{10,000}$ \\
\hline Net Income & $\$ 15,000$ & $\$ 15,000$ & $\$ 15,000$ & $\$ 15,000$ & $\$ 15,000$ \\
\hline Earnings per share & $\$ .15$ & $\$ .15$ & $\$ .15$ & $\$ .15$ & $\$ .15$ \\
\hline Shares outstanding & 100,000 & 100,000 & 100,000 & 100,000 & 100,000 \\
\hline
\end{tabular}

\footnotetext{
Bauer Company

Balance sheet 12/31/X5
}

\begin{tabular}{lccr}
\hline Cash & $\$ 225,000$ & Common stock & $\$ 100,000$ \\
& & Paid-in capital - & \\
& & Stock options & 100,000 \\
& & Retained earnings & $\underline{25,000}$ \\
Total Assets & $\$ 225,000$ & Liabilities and equity & $\$ 225,000$ \\
\hline
\end{tabular}


Over the five years the book value of the company rose from $\$ 1.00$ per share to $\$ 2.25$ per share. The net income for the five year period, however, totaled only $\$ .60$. The net income including the charge for employee stock options granted does not appear to reflect economic reality. We see that the effect of charging option values as compensation expense is that earnings are merely being capitalized into paid-in capital. This is the same action as a stock dividend.

Contrast the above example with an example of stock issued in order to acquire a depreciable asset. Then the cost of that asset is properly depreciated in order to assess the recovery of the cost to provide for the orderly replacement of the asset. Stock issued for employee compensation carries no such future implication. It is a period event. The income statements for the 5 years and balance sheet for the fifth year are provided in Exhibit 3 .

\section{EXHIBIT 3: Equipment Depreciated Over Its Useful Life}

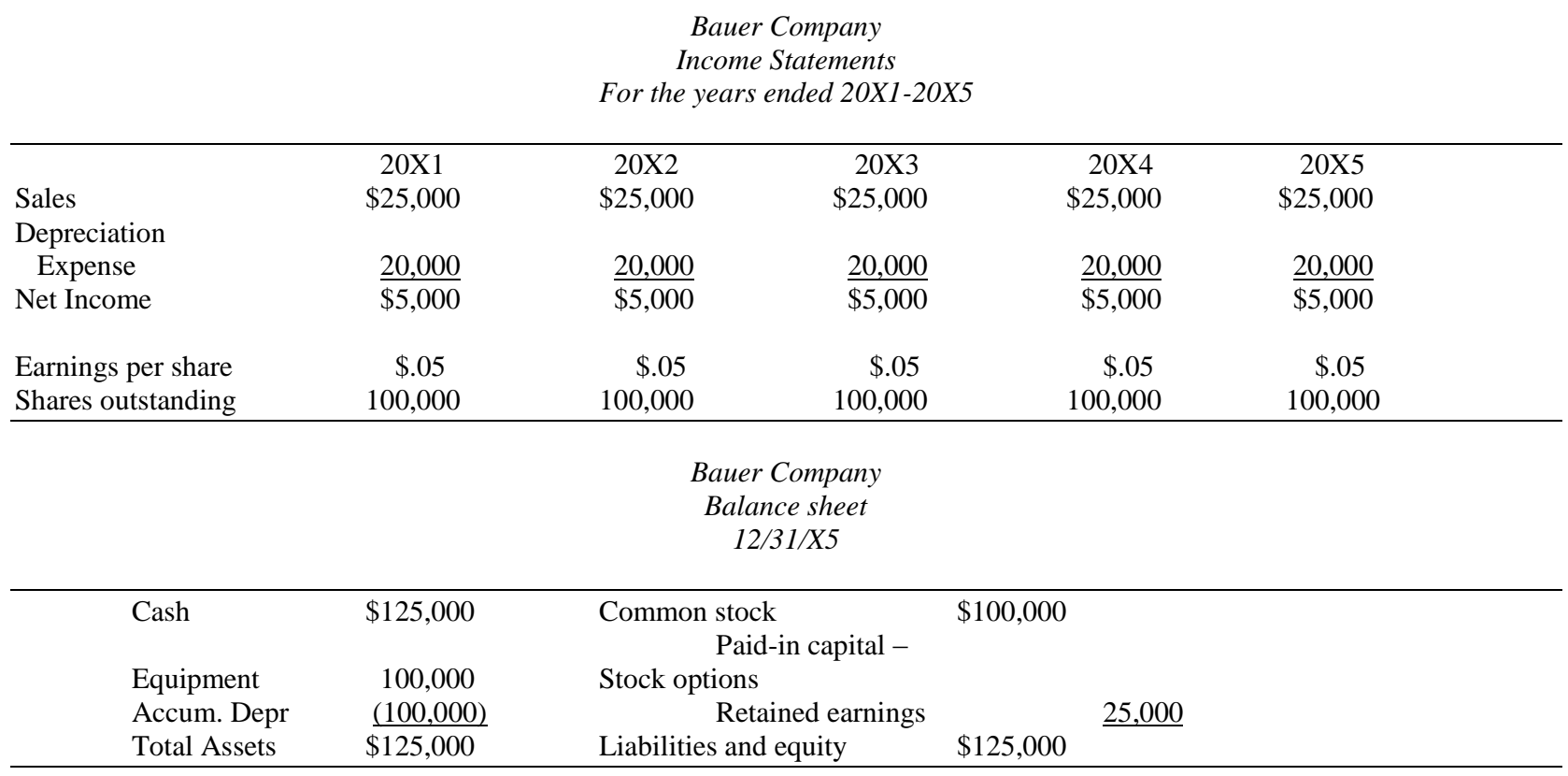

Over the five years the book value of the company rose from $\$ 1.00$ per share to $\$ 1.25$ per share. The net income for the five year period totaled $\$ .25$. The net income including the charge for depreciation does appear to reflect economic reality. The charge for depreciation is an allocation to represent the using up of an asset. It bears no resemblance to a dividend.

\section{SHARE APPRECIATION RIGHTS (SARS)}

Share appreciation rights (SARS) are equity instruments granted to employees that carry the promise to pay in cash the SARS value upon exercise of the SARS by the employee. Like stock options granted, compensation expense is recognized over the SARS vesting period. Unlike the expense for stock options granted, however, the expense/liability for cash settlement is accrued each period using fair value of the SARS.

Using the example from above, assume that the fair value of the SARS (market price of stock - exercise price) at December 31 each year is as provided in Panel A of Exhibit 4. 


\section{EXHIBIT 4: SARS Are Granted}

\section{Panel A: Fair Value of SARS}

\begin{tabular}{rrrrr}
\hline $20 \mathrm{X} 1$ & $20 \mathrm{X} 2$ & $20 \mathrm{X} 3$ & $20 \mathrm{X} 4$ & $20 \mathrm{X} 5$ \\
$\$ .05$ & $\$ .20$ & $\$ .15$ & $\$ .30$ & $\$ .60$ \\
\hline
\end{tabular}

Panel B: Financial Statements

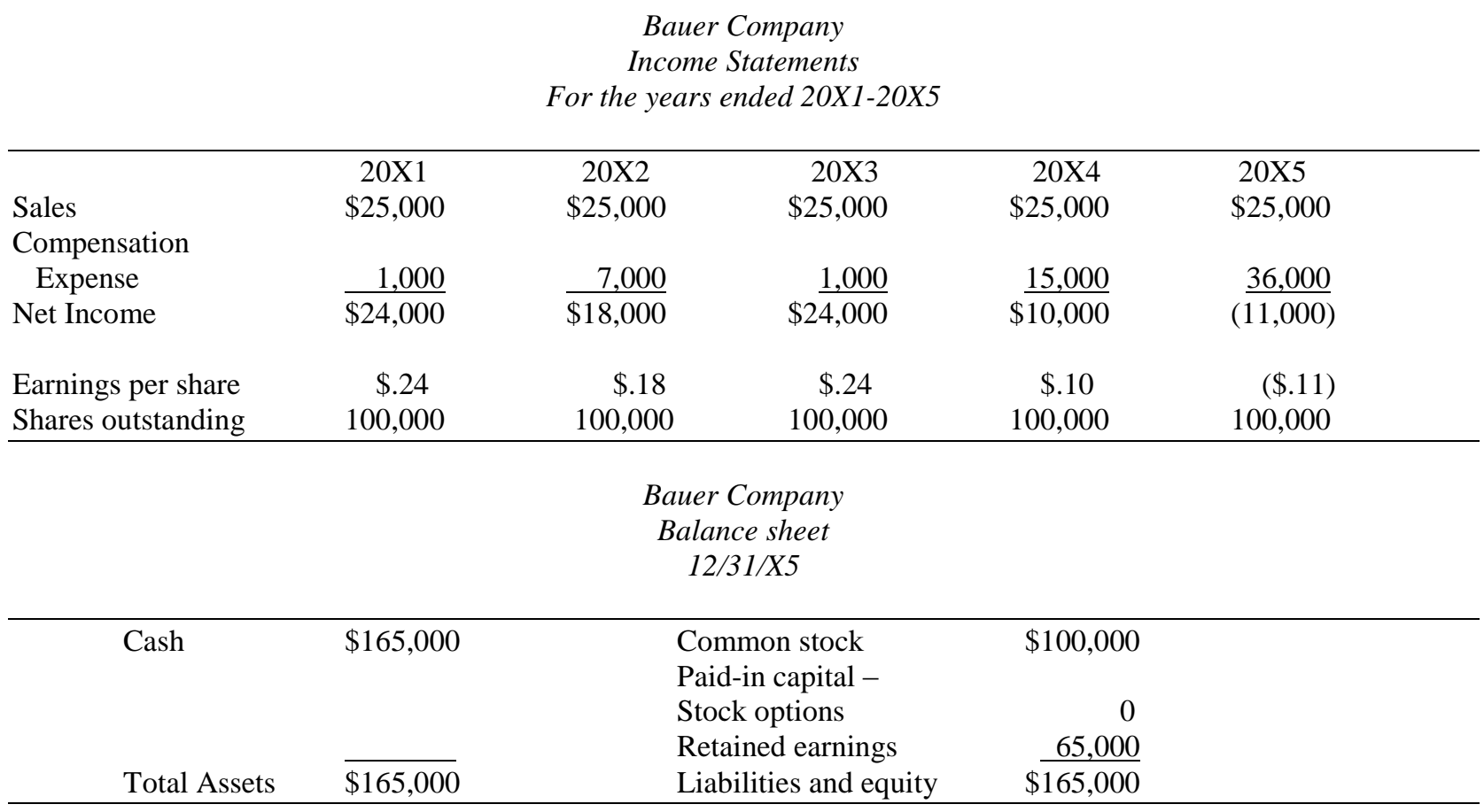

The expense for $20 \mathrm{X} 1$ then would be $\$ 1,000(100,000 \times \$ .05 \times 1 / 5)$. The debit to compensation is offset with a credit to a liability account, such as share-based compensation liability. In the second year the liability rises to $\$ 8,000(100,000 \times \$ .20 \times 2 / 5)$. An additional $\$ 7,000$ is charged to expense. At the end of $20 \mathrm{X3}$, the liability stands at $\$ 9,000(100,000 \times \$ .15 \times 3 / 5)$. An additional $\$ 1,000$ is charged to expense. At the end of $20 \mathrm{X} 4$ the liability rises to $\$ 24,000(100,000 \times \$ .30 \times 4 / 5)$. An additional $\$ 15,000$ is charged to expense. Finally, at the end of the vesting period the liability is $\$ 60,000(100,000 \times \$ .60 \times 1)$, and an additional $\$ 36,000$ is charged to compensation expense. The financial statements prepared under this assumption are provided in Panel B of Exhibit 4.

This result is appealing because it reflects economic reality. The company incurred a $\$ 60,000$ liability and paid it off with assets of the company.

\section{CRITIQUE OF EXPOSURE DRAFT AND CONCLUSION}

The Exposure Draft states that, "The objective of accounting for transactions under share-based payment arrangements with employees is to recognize as an expense in the income statement the cost to the entity of services received (and consumed) in exchange for equity instruments issued, or liabilities incurred." The Exposure Draft specifies that the compensation cost is determined by the fair value of the equity instruments issued. It does not allow for the alternative use of fair value of services provided if that is more clearly determinable. The fair value of the equity instruments is charged to expense over the requisite service period as services are rendered. The fair value of 
the equity instrument awarded shall not be remeasured after the grant date. We see in the exhibits that the proposed expensing of share-based payments often does not reflect economic reality. Sometimes, we have zero dollars and zero equity interests involved; nevertheless, we have a decrement to the corporation that affects bond holders and stockholders equally. Preposterous. When is the incidence of expense? Is there an expense or is the award a dividend? We believe that it is more like a stock dividend with conditions.

\section{REFERENCES}

1. Accounting Principles Board (APB). 1972. Accounting for Stock Issued to Employees. Opinion No. 25. New York: AICPA.

2. Barlas, S. 2002. Congress to take some action on stock options. Strategic Finance. (June 2002): 21-23.

3. Business Week. 2000. Executive pay scoreboard. Business Week (April 17, 2000).

4. Carlson, E. 1992. Stock-option proposal worries high-tech firms. Wall Street Journal (June 26).

5. Financial Accounting Standards Board (FASB). 1995. Accounting for Stock Based Compensation. Statement of Financial Accounting Standards No. 123. Stamford, Conn.: FASB.

6. Financial Accounting Standards Board (FASB). 2004. Share-Based Payment. Proposed Statement of Financial Accounting Standards. Stamford, Conn.: FASB.

7. Financial Accounting Standards Board (FASB). 2003. FASB Adds Projects to Its Agenda on Employee Stock Options and Pensions. Norwalk, CT: FASB. Retrieved November 24, 2003, from the Financial Accounting Standards Board Web site: http://www.fasb.org/news/nr031203.shtml

8. Gleckman, H. 2002. Options: It's time for companies to come clean. Business Week. (April 1): 35.

9. Henry, D., M. Conlin, N. Byrnes, M. Mandel, S. Holmes, and S. Reed. 2002. Too much of a good incentive. Business Week (March 4): 38-39.

10. Nagy, A. 2001. Financial Statement Fraud: Capital Market Effects and Management Actions Research in Accounting Regulation (15): 95-117.

11. Rubinstein, Mark. 1995. On the accounting valuation of employee stock options. Journal of Derivatives (Fall): 50-76.

12. Street, D., D. Fordham and A. Wayland. 1997. Stock options as a form of compensation for American executives: Impact on accounting rules of themes and arguments reported in newspapers and business magazines, Critical Perspectives on Accounting 8: 211-242.

13. Shapiro, Robert. 2002. The Options Problem: It started with Adam Smith, not Bernie Ebbers. Retrieved June 11, 2004, from the MSN Slate Web site: http://slate.msn.com/?id=2068693 